\title{
Solid Waste Management and Public Health Challenges: Appraisal of Local Government Capacity to Achieve Effective Environmental Governance
}

\author{
Ngozi Nwogwugwu ${ }^{1} \&$ Adebola Olubunmi Ishola ${ }^{1}$ \\ ${ }^{1}$ Department of Political Science and Public Administration, Veronica Adeleke School of Social Sciences, \\ Babcock University, Ilishan-Remo, Ogun State, Nigeria \\ Corresponding author: Ngozi Nwogwugwu. E-mail: nwogwugwun@babcock.edu.ng
}

Received: January 10, 2019

Accepted: February 27, 2019

Online Published: April 30, 2019

doi:10.5539/ass.v15n5p1

URL: https://doi.org/10.5539/ass.v15n5p1

\begin{abstract}
Solid waste management is an essential social service of the local government system in Nigeria. The lack of adequate funding of the local governments has created a situation where most of the cities are dirty as solid waste is disposed indiscriminately resulting to various public health issues. The establishment of the ecological fund has not provided effective relief to the problems of environmental governance, including solid waste management. The study examined the relationship between solid waste management and public health challenges in Ibadan city, Nigeria. The study adopted survey design, while the population of study was Ibadan city in Oyo State, Nigeria. Quantitative data was collected using validated questionnaire with response rate of $100 \%$. Correlation coefficient and ANOVA were employed in the testing of the hypotheses. The study found that there was significant relationship between Politicization of Waste Management and Public Health Challenges ( $r$ $=.325, p<.05)$. In addition, there was significant relationship between Ineffective Management of Solid Waste and Public Health Challenges $(r=.662, p<.05)$. Indiscriminate Disposal of Solid Waste, Politicization of Solid Waste and Ineffective Management of solid waste had joint significant effect on Public Health Challenges $\left(F{ }_{3}\right.$, $\left.{ }_{296}\right)=22.078$, Adj. $R^{2}=.696, p<0.05$ ). The study concluded that the politicization of solid waste management in the selected local governments had resulted in ineffective management of solid wastes, with the residents being exposed to several public health challenges. It was recommended that there should be improved funding of the waste management agencies to enable them adopt modern waste disposal techniques.
\end{abstract}

Keywords: solid waste; waste management, public health challenges, local government, environmental governance

\section{Introduction}

Solid waste management is among the essential services which the government is expected to provide for its citizens in Nigeria. By statute, it is the Local government that has the responsibility of managing waste in the country. It involves the collection, transport, processing as well as proper disposal of wastes that are generated from homes, commercial entities and even industrial establishments. The aim of solid waste management is to prevent or reduce the impact of waste on human health or local amenities.

According to Singh, Gupta, Chaudhary (2014, p. 347), "solid waste, also referred to as Municipal solid waste (MSW), includes wastes such as durable goods, nondurable goods, containers and packaging, food wastes yard wastes, and miscellaneous inorganic wastes from residential, commercial, institutional, and industrial sources." Solid wastes are residues or leftovers that are not unusable from raw materials, and scraps from industrial processing operations. Used or scraps of packaging materials and products that have been discarded after useage (Bhatia, 2013).

U.S. Environmental Protection Agency 1976 (cited in Singh, Gupta, \& Chaudhary, 2014, p. 347) writes that "a successful solid waste management system utilizes many functional elements associated with generation, on-site storage, collection, transfer, transport, characterization and processing, resource recovery and final disposal." Incidentally, some of those elements have not been applied in a functional manner in the management of solid waste generated in urban areas in Nigeria, including Ibadan city.

In Nigeria, of all the different categories of wastes generated in the country, solid wastes appear to pose the 
greatest challenge beyond the reach of various waste management agencies (Ogbonna, Amangabara, \& Ekere, 2007). Among the major setbacks in the efforts to manage solid waste in Nigeria include the unwholesome waste disposal habits of residents of various local governments as well as weak sanitation laws enforcement by the appropriate government officials (Babayemi \& Dauda, 2009).

Several scholars have published research work on various aspects of environmental governance in Nigeria, with most of them focusing on environmental problems resulting from increasing urbanization and high population density in Nigeria's major cities (Agboje, Adetola, \& Odafe, 2014; Ojo, Ogbole, \& Ojo, 2014; Muhammad \& Manu, 2013; Agwu, 2012; Mbalasi \& Ogoegbulam, 2012). While acknowledging that the Nigerian constitution entrusts local governments with the responsibility of managing the solid wastes in their areas of jurisdiction, none of these studies interrogated the capacity of the local governments to carry out this mandate (in terms of adequate funding and political autonomy) and the public health implications of ineffective management of solid waste by the local governments as a result of lack of capacity to fulfil the expected responsibilities.

Ibadan city, the largest city in West Africa, and the capital of Oyo State, one of Nigeria's 36 states is regarded as one of the dirtiest cities in Africa. This is in spite of the fact that the State government has established the Oyo Solid Waste Management Agency which is supposed to enhance the capacity of the local governments to effectively manage waste. The state government had also adopted the Public-Private Partnership (PPP) system in which private solid waste management companies are engaged to manage solid wastes in different local governments. However, there has been complaints from residents of the state that the private waste management companies are contracted on the basis of the political affiliation of their proprietors and that these companies lack the competence to effectively manage solid waste in the local governments, within the local government areas in the state, which exposes the residents therein to various public health challenges.

It is in the light of the foregoing that this study evaluated the ability of the local governments to effectively manage solid waste in Ibadan city of Oyo state, and appraised the various public health challenges inherent in ineffective management of solid waste in the area.

\section{Literature Review}

\subsection{Solid Waste Management}

Increasing urbanization across the world has resulted in increase in the volume of solid waste being generated. This cuts across countries and continents, regardless of their levels of development. This trend is clearly inferred in the following report by Psomopoulous, Bourka and Themelis (2009) with specific focus on the United States of America:

$$
\begin{aligned}
& \text { As is true everywhere in the world, the generation of municipal solid } \\
& \text { waste (MSW) in the USA has grown steadily, a survey carried out } \\
& \text { every two years by Columbia University and BioCycle Journal }
\end{aligned}
$$

(Simmons et al., 2016; Themelis \& Kaufmann, 2004) show that the generation of MSW increased from 335.80 million tonnes in 2002 to

351.90 in 2004 an increment corresponding to $2.5 \%$ rate per annum (p. 1718).

Onu, Price, Surendran, and Ebie (2012) explained that solid waste management involves the application of those techniques which are to ensure the orderly execution of all functions of collection, transfer, processing treatment and the disposal of solid wastes. This also entails the elimination of all those environmental issues that can impinge on the health of the citizens or diminish the aesthetics of the environment.

Various methods for managing solid waste exists. The most common methods adopted in the management of solid waste are landfilling, composting, recycling, mechanical-biological treatment and waste to energy (WTE) (Psomopoulos, Bourka, \& Themelis, 2009). However, the predominant methods adopted in the management of solid waste in Ibadan city are open dump site, landfilling and incineration (open burning). This is very unlike some cities in the developed countries where recycling, mechanical-biological treatment and waste to energy (WTE) are the more prominent methods adopted in management of solid waste.

The disposal of wastes in landfill sites has increasingly caused concern about possible adverse health effects for populations living nearby, particularly in relation to those sites where hazardous waste is dumped (Vrijheid, 2000). Adoption of waste incineration pose some health risks to residents. Studies suggest that there is some relationship between distance from the site and mortality or incidence from some cancers, such as lung cancers, 
childhood cancers and leukaemias (Elliott, Eaton, Shaddick, \& Carter 2000). This implies that people whose homes are close to the waste incineration sites are exposed to these forms of health risks. This is even worsened by the fact that most of these dumpsites are usually sited close to poor neighbourhoods, who have limited resources to take care of their health.

According to Ross (2012), the methods adopted for solid waste management have not kept up with lingering challenges and as such, there is a high proportion of uncollected wastes, poor standards of transportation, lack of proper treatment of wastes and poor methods of waste disposals. All these are causing serious concern with significant environmental, social and health costs especially in developing countries, where one observes open dumping of garbage which facilitates the breeding of disease vectors such as flies, mosquitoes, cockroaches, rats and other pests.

As reported by Uwadiegwu (2013), there are two major aspects or sides to waste management in Nigeria. There is the private sector side and the public sector side. Private sector participation is to offer ways of enhancing efficiency and reduce costs through the introduction of commercial principles. Private sectors will also be able to mobilise funds where the public sector is having difficulty doing so. To ensure that the capacity of the private sector is tapped where the public sector is handicapped, is one of the reasons for public-private partnerships in delivery of public services.

The public sector aspect has to do with the enabling policies and institutional mechanism for managing solid waste; which is predominantly at the local government level. Waste Management in most urban areas in Nigeria, like in most developing countries is influenced in numerous ways by the political context. The nature of politics at the local level/politicization affect the character of management, governance and the type of Management system which is adopted and applied in the delivery of public services (Adejobi \& Olorunnimbe, 2012).

According to Bakare (2016), most parts of Oyo state and in particular the city of Ibadan do not enjoy effective solid waste management services and as such, there has been resort to open dump sites, burying of the solid wastes and other forms of indiscriminate dumping of refuse which are forms of threat to public health. Adoption of modern methods of solid waste management services is costly and most local governments in Nigeria may not be able to adequately fund them. In most urban local governments especially those within the or around state capitals, state governments have taken over the responsibility of solid waste management through the various state environmental protection agencies. However, it has been observed that solid waste management agencies owned by the state governments are poorly funded. A lot of problems such as inadequate number of vehicles, lack of spare parts, dearth of fund, poor technical know-how, poor maintenance practices, insufficient funding and lack of motivation has be devilled the agency responsible for the disposal and collection of waste (Adewole, 2009; Ogwueleka, 2009)

\subsection{Public Health Implications of Ineffective Management of Solid Waste}

The adoption of open dumpsites as means of managing solid waste in many urban cities especially in the developing countries had resulted in indiscriminate disposal of solid waste in such cities. The fact that these dump sites are not properly controlled makes them major health threats to people living near those areas (Sood, 2004 cited in Sankoh, Yan \& Tran, 2013). The United Nations Environment Program Agency (UNEPA) (2006) stated that wastes that are not managed properly, especially solid wastes from households and communities constitute a serious health hazard which can lead to the spread of diseases.

The report further stated that unattended wastes lying around attract flies, rats, and other creatures that, in turn spread diseases. Normally, it is the wet waste that decomposes and releases a bad odour. The bad odour affects the people settled next to the dumpsite, which shows that the dumpsites have serious effects to people settled around or next to them. The groups that are at risk following the unscientific disposal of solid waste include; the population in areas where there is no proper waste disposal method, especially the pre-school children, waste workers and workers in facilities producing toxic and infectious materials (Sankoh, Yan, \& Tran 2013, p. 666).

Other high-risk groups include population living close to the waste dump (Aatamila, Verkasalo, Korhonen, Viluksela, Pasanen, Tiittanen, \& Nevalainen, 2010) as well as workers engaged in management of wastes. When those who directly work on the waste dumpsites and landfills are not provided with sufficient protective 
materials, they are exposed to health hazards. The incidence of occupational accidents in waste collection workers has been found to be higher than the general workforce (Poulsen et al., 1994). This as a result of the fact that those category of workers come in direct contact with the waste and are more likely to be affected by contaminated waste than other category of workers who are not engaged in such responsibilities.

Although, results that provide links between exposure to gases from indiscriminate disposal of waste to mortality and morbidity have been inconsistent between cities and studies, it is certain that there are risk of health hazards from such exposure (Zanobetti, Schwartz, \& Gold, 2000). Studies have also shown that direct handling of solid waste can lead to contracting different types of infectious and chronic diseases by unsuspecting residents with the waste management workers directly involved in the collection of these wastes and dump site scavengers being the most vulnerable (Zirana, Tilahu, \& Mberu, 2016; Nwanta \& Ezenduka, 2010).

A study conducted by Yongsi, Herrmann, Lutumba-Ntetu, Sietchiping, and Bryant (2008) showed that exposure to hazardous waste in dumpsites can affect human health, and most often, it is the children who are the most vulnerable to these pollutants. Direct exposure to these harmful substances at the open dump sites can lead to diseases through chemical exposure to unsuspecting members of the public. Open dumpsites are a major problem to the environment especially to the air being inhaled. Dumpsites emit obnoxious odours and smoke that cause illness to people living in, around, or closer to them (Marshal, 1995). According to Kola-Olusanya, Omotayo and Fagbohun (2011), there are other health implications of improper management of solid waste which includes contracting water-borne diseases, such as typhoid, cholera, meningitis, polio, hepatitis. These are diseases that result from water that has been contaminated by human, animal or other form of wastes. The poorly managed dumpsites can also serve as breeding ground for such vectors like mosquitoes, tsetse flies and others that infect humans with malaria, yellow fever, dengue fever, sleeping sickness and some other related diseases.

Adewole (2009) hold similar view on the vectors and possible diseases that could be contracted through exposure as a result of improper management of solid waste:

flies which carry germs on their bodies and legs and also excrete them; mosquitoes breed in stagnant water in blocked drains in favourable location in cans, tyres etc. that collects rain water; Rats: rat's spreads typlius, salmonella, leptospirosis and other diseases they cause injuries by biting and spoil millions of tons of food. The refuse workers also faces some hazards which includes: parasite infection and infected cuts resulting from skin contact with refuse, other includes hazards on disposal sites; are injuries from glass, razor blades, syringes, tissue damage or infection through respiration, ingestion or skin contact (p. 175).

There are certain volatile compounds (example are ammonia, hydrogen sulphide and similar derivatives, acids of lower molecular weight, esters and other detectable oxides and oxygen) that are found in industrial solid wastes and these are very dangerous as they are hazardous components. Domestic wastes which can come from cattle farm house and agro farmhouse wastes contribute gases similar to that of biogas and are also dangerous.

\section{Methodology}

The study adopted survey design. The study population was Oyo State, which has 33 local governments. Akinyele, Egbeda and Ibadan North East local governments were purposively selected for the study, because they are densely populated and among the local governments where public-private partnership (PPP) waste management companies appointed by the state government are functional. Stratified random sampling technique was employed to select 300 respondents for the purpose of data collection. Copies of validated questionnaire were administered to 300 respondents from the 3 selected local governments. The number of respondents selected from each of the local governments was done according to the proportion of the population of each local government. Ibadan North East which has the highest population according to the National Population Commission census figures of 2006, had the highest number of respondents 104 out of the total 300 .

Among the respondents were officials of the local government, including WESCOM of the local governments, officials of Oyo State Solid Waste Management Board, Officials of the Public - Private Partnership (PPP) companies involved in solid waste management in the state, executives of various market men and women associations in the selected local governments, community leaders and residents of the local governments. The field survey was conducted between the months of February and July 2017. Data were analysed using descriptive 
statistics while Correlation coefficient and ANOVA were employed in testing the hypotheses at $5 \%$ significance level. The hypotheses were:

$\mathrm{Ho}_{1}$ : There is no significant relationship between politicization of waste management and public health challenges.

$\mathrm{Ho}_{2}$ : There is no significant relationship between ineffective management of solid waste and public health challenges.

$\mathrm{Ho}_{3}$ : There is no significant relationship between indiscriminate disposal of solid waste and public health challenges.

$\mathrm{Ho}_{4}$ : There is no significant joint effect of indiscriminate disposal of solid waste, politicization of solid waste and ineffective management on public health challenges.

\section{Findings and Discussion}

Table $1 . \mathrm{Ho}_{1}$ : There is no significant relationship between politicization of waste management and public health challenges

\begin{tabular}{ccccccc}
\hline Variable & Mean & Std. Dev. & N & R & P & Remark \\
\hline Politicization of Waste Management & 10.0200 & 2.204 & & & & \\
& & & & & & \\
Public Health Challenges & 17.2367 & 3.1992 & 300 & $.325^{* *}$ & .000 & Sig. \\
\hline
\end{tabular}

** Sig. at .01 level, * Sig. at .05 level

Source: Researchers field survey (2017).

Table 1 shows a significant relationship between politicization of waste management and public health challenges $\left(r=.325^{* *}, p<.05\right)$. The null hypothesis is thus rejected.

Most of the respondents reported that PPPs that manage solid waste in their areas were not appointed based on their competence or track record in management of solid waste. Rather, they were appointed as a form of political settlement for the owners of such companies who were prominent politicians in the state. This agrees with earlier studies by Adejobi \& Olorunnimbe (2012) which found that the management of solid waste is influenced by the political context at the local government level. The politicization of solid waste management in Ibadan city had resulted in ineffective management of solid waste as the companies operating the PPPs, lack competent personnel who are trained in modern methods of managing solid waste. This finding corroborates the earlier study of Ogwueleka (2009) which found that lack of expertise staff engaged in solid waste management programme in Nigeria had plagued efforts by various governments to solve the problem solid waste in the country. The politicization of solid waste management had resulted in ineffective management of solid waste in Ibadan City, with attendant public health challenges.

Table $2 . \mathrm{Ho}_{2}$ : There is no significant relationship between Ineffective management of solid waste and public health challenges

\begin{tabular}{ccccccc}
\hline Variable & Mean & Std. Dev. & $\mathrm{N}$ & $\mathrm{R}$ & $\mathrm{P}$ & Remark \\
\hline $\begin{array}{c}\text { Ineffective management disposal of } \\
\text { Solid Waste }\end{array}$ & 16.4367 & 3.5957 & & & & \\
$\begin{array}{c}\text { Public Health Challenges } \\
\text { Put Hig. }\end{array}$ & 17.2367 & 3.1992 & 300 & $.662^{* *}$ & .000 & Sig \\
\hline
\end{tabular}

** Sig. at .01 level, * Sig. at .05 level

Source: Researchers field survey (2017)

Table 2 shows a significant relationship between ineffective management of solid waste and public health challenges $\left(r=.662^{* *}, p<.05\right)$. The null hypothesis is thus rejected.

The ineffective management of solid waste in the selected areas results in exposure of residents to contaminants and disease vectors with attendant health challenges. In addition, adoption of waste incineration exposes them to various emission of greenhouse gases, which affects global warming with attendant health challenges to the residents. 
The appointment of incompetent PPPs on the basis of their being owned by political associates of those at the helm of affairs at the state level to manage solid waste in the local governments had resulted in a situation where there is ineffective management of solid wastes in the selected local governments. The PPPs lack the expertise and do not utilize modern equipment for managing solid wastes. The ineffective management of solid waste in Ibadan city is exemplified by the adoption of outdated practices such as burning of solid wastes, and open dump sites as well as disposal of wastes in landfill sites, which pose public health challenges to residents of the sampled local governments. This findings is in agreement with an earlier study by Elliott, Eaton, Shaddick, Carter (2000) which found that waste incineration exposes people to risk of diseases such as cancers. In addition, the burning of solid wastes increases the incidences of global warming with attendant public health issues. The study also corroborates the finding of Vrijheid (2000) that the disposal of wastes in landfill sites has poses threat to the health of nearby residents.

Table 3. $\mathrm{Ho}_{3}$ : There is no significant relationship between indiscriminate disposal of solid waste and public health challenges

\begin{tabular}{ccccccc}
\hline Variable & Mean & Std. Dev. & $\mathrm{N}$ & $\mathrm{R}$ & $\mathrm{P}$ & Remark \\
\hline Indiscriminate Disposal of Solid Waste & 12.7333 & 2.7979 & & & & \\
Public Health Challenges & 17.2367 & 3.1992 & 300 & $.781^{* *}$ & .000 & Sig. \\
\hline
\end{tabular}

** Sig. at .01 level, * Sig. at .05 level

Source: Researchers field survey (2017)

Table 3 shows a significant relationship between indiscriminate disposal of solid waste and public health challenges $\left(r=.781^{* *}, p<.05\right)$. The null hypothesis is thus rejected.

Most of the respondents agreed that indiscriminate dumping of refuse around homes and the location of official open dumpsites close to homes posed public health challenges to residents, as the dumpsites served as breeding ground for disease vectors, insects and rodents. The fact that the open dump sites are uncontrolled means that children living close to them, play around the dumpsites unprotected, exposing them to major health threats. This finding is in agreement with earlier studies which found that uncontrolled disposal of waste result in some health hazards, as the waste dumps as breeding grounds for insects, rodent (rats) and pathogenic bacteria which are diseases vectors such as mosquitoes, cockroaches, houseflies, leading to spread of diseases like malaria, cholera, diarrhoea, among others (Ogwueleka,2009). According to Sood (2004 cited in Sankoh, Yan, \& Tran (2013), the ills of inappropriately disposed of municipal solid wastes include health deterioration, accidents, flood occurrences, and environmental pressures. The finding also corroborates earlier findings of Sankoh et al (2013, p. 669) that "majority of both nearby and far away residents indicated that the dumpsite is the breeding place for disease vectors, cause diseases, and makes the place dirty" (Sankoh et al., 2013, p. 669). In addition, there are no measures put in place by the state or local government authorities to protect people residing close to dumpsites from possible harmful effects.

Table 4. ANOVA showing the joint effect of the independent variables (indiscriminate disposal of solid waste, politicization of solid waste and ineffective management) on public health challenges

\begin{tabular}{|c|c|c|c|c|c|c|}
\hline $\mathrm{R}$ & & \multicolumn{2}{|c|}{ R Square } & Adjusted R Square & \multicolumn{2}{|c|}{ Std. Error of the Estimate } \\
\hline .836 & & \multicolumn{2}{|c|}{.699} & .696 & \multicolumn{2}{|c|}{1.7642} \\
\hline \multicolumn{7}{|c|}{ ANOVA } \\
\hline Model & Sum of Squares & $\mathrm{DF}$ & Mean Square & $\mathrm{F}$ & Sig. & Remark \\
\hline Regression & 2138.931 & 3 & \multirow{3}{*}{$\begin{array}{c}712.977 \\
3.112\end{array}$} & \multirow{3}{*}{22.078} & \multirow{3}{*}{.000} & \multirow{3}{*}{ Sig. } \\
\hline Residual & 921.266 & 296 & & & & \\
\hline Total & 3060.197 & 299 & & & & \\
\hline
\end{tabular}

Source: Researchers field survey (2017).

Table 4 shows the joint effect of the independent variables (Indiscriminate Disposal of Solid Waste, Politicization of Solid Waste and Ineffective Management) to the prediction of Public Health Challenges was 
significant. The table also shows a coefficient of multiple correlation $\left(R=.836\right.$ and a multiple $\left.R^{2}=.699\right)$ and Adjusted $R^{2}=.696$. This means that 69.6 of the variance was accounted for by the predictor variables when taken together. The significance of the composite contribution was tested at $p<.05$. The table also shows that the analysis of variance for the regression yielded an $\mathrm{F}(3,296)=22.078$, (significant at 0.05 level). This implies that the joint contribution of the independent variables to the dependent variable was significant and that other variables not included in this model may have accounted for the remaining variance.

\section{Conclusion}

It is evident that solid waste management in the sampled local governments is plagued with inefficient collection methods, insufficient coverage of the collection system, and improper disposal of waste by residents, as well as insufficient financial resources being allocated by the local government management. Furthermore the solid waste management outfits engage of utilization of inappropriate technology, poor data information for planning, wrong attitude of waste generator amongst others.

The politicization of solid waste management by the state government, whereby contracts for the management of solid wastes in various local governments are awarded to cronies and political associates as tool of political settlement, has degraded the ability of the local governments to manage solid wastes. Politicization of solid waste management should be discouraged. Only competent firms with pedigree in the management of solid wastes and capability to establish waste recycling plants should be engaged to manage solid wastes. This would ensure the adoption of modern techniques of solid waste management.

The adoption of open dump sites, some of which are close to residential areas are a major threat to public health in Ibadan City, Oyo state. There is the increased possibility of epidemic outbreak as a result of exposure to decomposing toxic substances, especially when waste management workers and scavengers do not wear adequate protective coverings.

The adoption of old practices of burning solid wastes at dump sites from time to time increase the rate of carbon emission into the atmosphere, which depletes the ozone layer with attendant public health challenges. There is no waste recycling plant in the state, which is a very big misnomer in the $21^{\text {st }}$ century. The government should establish waste recycling plants in the State which will facilitate effective management of solid waste as well as create jobs and wealth for the residents of the local governments.

\section{References}

Aatamila, M., Verkasalo, P. K., Korhonen, M. J., Vilksela, M. K., Pasanen, K., Tiittanen, P., \& Nevalainen, A. (2010). Odor Annoyance near Waste Treatment Centres: A Population-Based Study in Finland. Journal of Air and Waste Management Association, 60(4), 412- 418. https://doi.org/10.3155/1047-3289.60.4.412

Adejobi, O. S., \& Olorunnimbe, R. O. (2012). Challenges of Waste Management and Climate Change in Nigeria: Lagos State Metropolis Experience. African Journal of Scientific Research, 7(1), 346-362.

Adewole, A. T. (2009). Waste management towards sustainable development in Nigeria: A case study of Lagos state. International NGO Journal, 4(4), 173-179. Retrieved from http://www.academicjournals.org/INGOJ

Agboje, I, Adetola, A., \& Odafe, I. B. (2014). Performance Assessment of Solid Waste Management following Private Operations in Lagos State, Nigeria. Journal of Waste Management, 1-8. https://doi.org/10.1155/2014/868072

Agwu, M. O. (2012) Issues and Challenges of Solid Waste Management Practices in Port-Harcourt City, Nigeriaa behavioural perspective. American Journal of Social and Management Sciences, 3(2), 83-92. https://doi.org/10.5251/ajsms.2012.3.2.83.92

Babayemi, J. O., \& Dauda, K. T. (2009). Evaluation of Solid Waste Categories and Disposal Options in Developing Countries: A Case Study of Nigeria. Journal of Applied Science and Environmental Management, 13(3), 83-88.

Bakare, W. (2016). Solid waste management in Nigeria. Retrieved from https://www.bioenergyconsult.com/solid-waste-nigeria/

Bhatia, S. C. (2013). Environmental Chemistry. Chennai, India: CBS Publishers \& Distributors Pvt Ltd.

Chandak, S. P. (2010). Trends in Solid Waste Management: Issues, Challenges and Opportunities. International Consultative Meeting on Expanding Waste Management Services in Developing Countries, 18-19 March 2010, Tokyo, Japan. Retrieved from https://www.scirp.org/(S(351jmbntvnsjt1aadkposzje))/reference/ReferencesPapers.aspx?ReferenceID=7756 
05

Dewani, J. M., \& Sudarshan, K. N. (2014). Solid Waste Management. New Delhi: Discovering Publishing House.

Kola-Olusanya, Omotayo, \& Fagbohun (2011). Environment and Sustainability: Issues, Policies and Contentions. Ibadan: University Press, Plc.

Marshal, E. (1995). Analytical Study to Evaluate Associations between Dumpsites and Birth Effects. Atlanta: ATSDR Co. Ltd.

Mbalasi, O. F., \& Ogoegbulam, O. B. (2012). Imperatives of Environmental Education and Awareness Creation on Solid Waste Management in Nigeria. Journal of Academic Research International, 3(2), 253-258.

Muhammad, M. N., \& Manu, I. O. (2013). Gender Roles in Informal Solid Waste Management in Cities of Northern Nigeria: a Case Study of Kaduna Metropolis. Academic Research International, 4(5), 142-153.

Nwanta, J. A., \& Ezenduka, E. (2010). Analysis of Nsukka Metropolitan Abattoir Solid Waste in South Eastern Nigeria: Public Health Implications. Archives of Environmental and Occupational Health, 65(1), 21- 26. https://doi.org/10.1080/19338240903390263

Ogbonna, D. N., Amangabara, G. T., \& Ekere, T. O. (2007). Urban solid waste generation in Port Harcourt metropolis and its implications for waste management. Management of Environmental Quality: An International Journal, 18(1), 71-88.

Ogwueleka, T. C. (2009). Municipal Solid Waste Characteristics and Management in Nigeria. Iran. J. Environ. Health. Sci. Eng., 6(3), 173-180.

Ojo, A. M., Ogbole, E. O., \& Ojo, A. O. (2014). Analysis of Improved Household Solid Waste Management System in Minna Metropolis, Niger State, Nigeria. Scientific Papers Series Management, Economic Engineering in Agriculture and Rural Development, 15(2), 237-242.

Onu, B., Price, T., Surendran, S. S., \& Ebie, S. (2012). Solid Waste Management: A Critique of Nigeria's Waste Management Policy. The International Journal of Knowledge, Culture and Change Management, 12, 1-22. Retrieved from http://www.management-Journal.com

Poulsen O. M., Breum, N. O., Ebbehøj, N., Hansen, A. M., Ivens, U. I., van Lelieveld, D. ... Wilkins, C. K. (1995). Collection of domestic waste. Review of occupational health problems and their possible causes. Science of the Total Environ, 170, 1-19.

Psomopoulos, C. S., Bourka, A., \& Themelis, N. J. (2009). Waste to energy: A review of status and benefits in USA. Waste Management, 29, 1718-1724. https://doi.org/10.1016/j.wasman.2008.11.020

Ross, A. (2012). Sustainable Development Law in the UK: From rhetoric to reality? New York: Earthscan Routledge.

Rushton, L. (2003). Health Hazards and Waste Management. British Medical Bulletin, 68(1), 183-197.

Sankoh, F. P., Yan, X., \& Tran, Q. (2013). Environmental and Health Impact of Solid Waste Disposal in Developing Cities: A Case Study of Granville Brook Dumpsite, Freetown, Sierra Leone. Journal of Environmental Protection, 4, 665-670. https://doi.org/10.4236/jep.2013.47076

Singh, G. K., Gupta, K., \& Chaudhary, S. (2014). Solid Waste Management: Its Sources, Collection, Transportation and Recycling. International Journal of Environmental Science and Development, 5(4), 347-350. https://doi.org/10.7763/IJESD.2014.V5.507

Tyokumbur, E. (2010). Environmental Practices for Human Well-being. Ibadan: Hope Publications.

United Nations Environment Program Agency (UNEPA). (2006). Informal Solid Waste Management. Retrieved from http://www.unep.org?PDF/Kenyawastemngntsector/chapt er1.pdf

Uwadiegwu B. O. (2013). The structural profile of the socio-economic and housing problems of the slum area in Enugu City, Nigeria; An Insider's Perception. Int. J. Eng. Sci., 2(3), 8-14.

Vrijheid, M. (2000). Health Effects of Residence near Hazardous Waste Landfill Sites: A Review of Epidemiologic Literature. Environ Health Perspect, 1(8), 101-112. Retrieved from http://ehpnetl.niehs.nih.gov/docs/2000/suppl-1/101-1 12vrijheid/abstract.html

Yongsi, H. B. N., Herrmann, T. M., Lutumba-Ntetu, A., Sietchiping, R., \& Bryant, C. (2008). Environmental Sanitation and Health Risks in Tropical Urban Settings: Case study of Household Refuse and Diarrhea in 
Yaoundé-Cameroon. International Journal of Human and Social Sciences, 3(3), 220-228.

Zanobetti, A., Schwartz, J., \& Gold, D. (2000). Are there sensitive subgroups for the effects of airborne particles? Environmental Health Perspectives, 108, 841-845

Ziraba, A. K., Haregu, T. N., \& Mberu, B. (2016). A review and framework for understanding the potential impact of poor solid waste management on health in developing countries. Archives of Public Health, 74(55), 1-11. https://doi.org/10.1186/s13690-016-0166-4

\section{Copyrights}

Copyright for this article is retained by the author(s), with first publication rights granted to the journal.

This is an open-access article distributed under the terms and conditions of the Creative Commons Attribution license (http://creativecommons.org/licenses/by/4.0/). 